\title{
Occurrence and chemistry of co-contamination of nitrate and hydrocarbon pollutants in gas-flared areas of Niger-Delta, Nigeria
}

\author{
Haruna Adamu 1, 3, *, Bappah Adamu Umar ${ }^{2,4}$ \\ ${ }^{1}$ Department of Chemistry, University of Aberdeen, Scotland, UK \\ ${ }^{2}$ Department of Geology and Petroleum Geology, University of Aberdeen, Scotland, UK \\ ${ }^{3}$ Department of Environmental Management Technology, Abubakar Tafawa Balewa University, Bauchi, Nigeria \\ ${ }^{4}$ National Centre for Petroleum Research and Development, Energy Commission of Nigeria, Abubakar Tafawa Balewa University \\ Research Centre, Bauchi, Nigeria
}

Email address:

aisonhardo2003@yahoo.com(H. Adamu)

\section{To cite this article:}

Haruna Adamu, Bappah Adamu Umar. Occurrence and Chemistry of Co-contamination of Nitrate and Hydrocarbon Pollutants in GasFlared Areas of Niger-Delta, Nigeria. International Journal of Environmental Monitoring and Analysis. Vol. 1, No. 4, 2013 , pp. $154-161$. doi: $10.11648 /$ j.ijema.20130104.17

\begin{abstract}
Scattered literature is harnessed to critically review the prime source, chemistry and potential environmental and health effects of co-contamination of nitrate and hydrocarbon pollutants commonly found in soils and surface- and groundwaters of Niger-Delta region of Nigeria, which substantially resulted from oil and gas exploration and exploitation via gas flaring of associated natural gas of crude oil. Gas flaring in Niger-Delta has impacted on the nitrate and hydrocarbon pollution of the region and thus, brought out attendant environmental and public health implications in the region. The historic trend of gas flaring presented by Nigerian National Petroleum Corporation and estimates of nitrogen oxides $\left(\mathrm{NO}_{\mathrm{x}}\right.$, the precursor of nitrate), hydrocarbons and volatile organic compounds presented by Shell-Nigeria suggest that amounts in excess of cubic meters of these are continuously generated year-in and year-out has established the cocontamination of nitrate and organic pollutants in the region. Therefore, as the problem now is brought out conspicuously, the paper could contribute in the justification of the existence of the co-contamination, which could serve as an ignition key for the investigation of an appropriate remediation technique that can simultaneously remove/degrade nitrates that co-exist with organic pollutants.
\end{abstract}

Keywords: Co-Contamination, Nitrate, Organic, Pollutants, Niger-Delta

\section{Introduction}

Before the technological age, environmental pollution/contamination was due to naturally occurring phenomena such as bush burning, volcanic eruption and very little from human activities. With advent of the industrial revolution and the increase in the technological innovations in Western Europe, e.g. the availability of steam powered devices, the utilization of fossil fuels increase the capacity of society to manipulate the earth's resources and process materials [1-3]. The net impact was to advance civilization and enhance socio-economic wellbeing of society, and as a direct result of the incomplete efficiency of these processes, release of residual materials to the atmospheric, aquatic, terrestrial environment occurred [2]. As such, today, Niger-Delta is currently suffering under pollution/ contamination stress as a result of discharge of pollutants/contaminants from exploration and exploitation of petroleum resources.

Niger-Delta is a host to many oil and gas industries with activities ranging from oil and gas exploration to servicing of oil and gas installations. The activities of these industries are being gradually destroying the endowed ecosystem of the region as encapsulated in the 1983 Nigerian National Petroleum Cooperation (NNPC) report, cited in United State Environmental Impact Assessment Report [4]. In the same vein, Eteng [5] argued that oil exploration activities over the past forty years has impacted negatively on the socio-physical environment of the oil-bearing communities, massively threatening the subsistence peasant economy, the environment and hence the entire livelihood and survival of the people. It is an incontestable fact; exploration and exploitation of petroleum resources has sumptuous 
economic implication for a country. However, activities of oil companies as perceived by environmentalists have various, negative impacts on the environment. One such practice associated with the extraction and refining of crude oil that is known to produce colossal amount of oil and gasgenerated pollutants is the flaring of gas into the atmosphere (see Fig. 1). Thus, combustion by-products of gas flaring including multiple organic contaminants such as benzene, toluene, xylene, polyaromatic hydrocarbons (PAHs), low molecular linear aliphatic, as well as sulphur dioxide, nitrogen dioxides are routinely released into the natural environment. Therefore, this paper is targeted to centre discussion on the co-contamination of nitrate and hydrocarbons pollutants resulting from gas flaring in NigerDelta, Nigeria, since nitrate and organic pollutants coexist in the natural environment, particularly in aqueous systems and, are of great concern because of their negative impact on both environment and the human health. Explicitly, as part of the many by-products of gas flares, nitrate and toxic hydrocarbons (e.g. benzene and its metabolites) are well known carcinogens, which have led to many suggestions of possible serious health implications for the residents of communities around gas flaring sites [6-8].

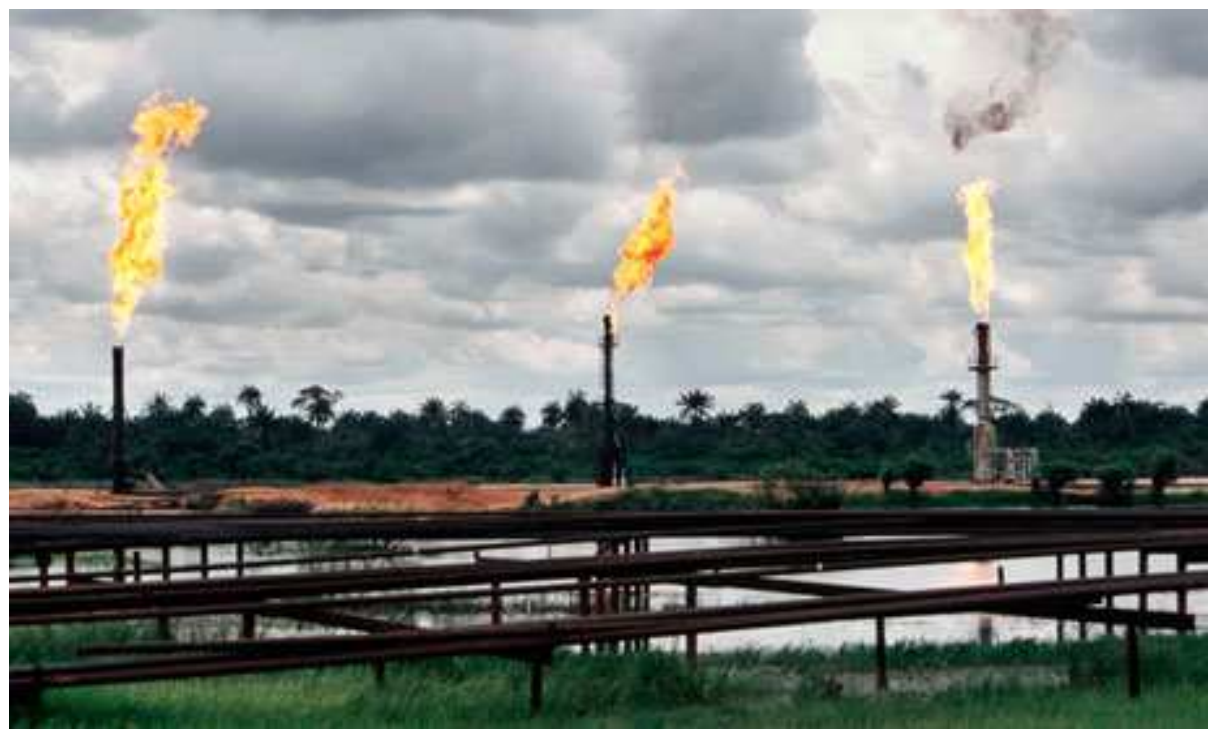

Fig. 1. Gas flaring in Niger-Delta, Nigeria. Source: [9].

\subsection{Gas Flaring in Nigeria}

The continued act of gas flaring in the Niger-Delta, which has reached world record levels, is directly linked to the activities of the multinational companies namely: Shell, Exxon

Mobil, Chevron Texaco, Agip and Total FinaElfin concert with the Nigerian National Petroleum Corporation (the state owned oil company). It is astonishing that despite the act of gas flaring in Nigeria being declared illegal in 1984, this as a result of the Associated Gas Reinjection Act of 1979, gas flaring continues unabated. The reasons for this are rather complex and seem intractable for a number of reasons [10].

At the onset of oil exploration in Nigeria, associated natural gas was deemed to be a waste product that resulted from the process of removing crude oil from the ground. This perception was indeed the dominant thought in the industry at the time and fortunately has a tracked record (Table 1). Thus, the practice became institutionalized and operational throughout the industry and therefore, this made Nigeria the second largest gas flaring volume among the top 20 individual countries (Table 2), from which Nigeria together with Russia account for $40 \%$ of global gas flaring and the top twenty countries account for $85 \%$ [11].
This inaction, on the part of the government and the multinational oil companies can be traced to the fact that the Nigerian oil industry is steeped in corruption; which has been to the benefit of the ruling local elite. As a result, policies of best practice that should underpin the activities within the industry are non-existent and thus this has had a lasting impact on the continued flaring of gas (Table 3), from which environmentally hazardous gases are emitted into the atmosphere and subsequently ended-up in terrestrial and aquatic ecosystems. Although there have been measures to try and capture the flared gas through the setting up of the Bonny LNG project in 1989 together with other gas gathering projects, these measures have been largely futile [10]. The measures have been fraught with operational and bureaucratic challenges with the attendant losses to the economy [12]. This can further be proven by the plots (Fig. 2) of annual flaring efficiencies for top eight gas flaring countries, in which Nigeria was found to be the worst among the top eight flaring countries and Saudi Arabia consistently out performs the other top flaring countries implying that it is quite efficient in managing gas flaring via utilisation of associated gas [11]. On the other hand, the continued and unabated flaring of gas, which constitutes $75 \%$ of gas produced [10], also means more damage is being wrought on the local ecology and on the 
environment as a whole. Indeed, the environmental cost of gas flaring is very high; the effects with regards to vegetation, aquatic ecosystem and the human health are hair-raising. Therefore, from these antecedents, one should expect extremely large amount of co-contamination of nitrate and hydrocarbon pollutants in soil and aquatic systems of the gas-flared areas of Niger-Delta, which has impacted negatively on the environment and human health of the region.

Table 1. Nigerian Natural Gas Production and Disposal in Million Cubic Metres $(1961$ - 2009).

\begin{tabular}{cccc}
\hline Year & Gas Produced & Gas Utilised & Gas Flared \\
\hline $\mathbf{1 9 6 1}$ & 310 & NA & NA \\
$\mathbf{1 9 6 2}$ & 486 & NA & NA \\
$\mathbf{1 9 6 3}$ & 626 & NA & NA \\
$\mathbf{1 9 6 4}$ & 1,029 & NA & NA \\
$\mathbf{1 9 6 5}$ & 2,849 & 116 & 2,733 \\
$\mathbf{1 9 6 6}$ & 2,908 & 216 & 2,692 \\
$\mathbf{1 9 6 7}$ & 2,634 & 102 & 2,532 \\
$\mathbf{1 9 6 8}$ & 1,462 & 151 & 1,311 \\
$\mathbf{1 9 6 9}$ & 4,126 & 64 & 4,062 \\
$\mathbf{1 9 7 0}$ & 8,068 & 111 & 7,957 \\
$\mathbf{1 9 7 1}$ & 12,996 & 206 & 12,790 \\
$\mathbf{1 9 7 2}$ & 17,122 & 274 & 16,848 \\
$\mathbf{1 9 7 3}$ & 21,882 & 395 & 21,487 \\
$\mathbf{1 9 7 4}$ & 27,170 & 394 & 26,776 \\
$\mathbf{1 9 7 5}$ & 18,656 & 323 & 18,333 \\
$\mathbf{1 9 7 6}$ & 21,274 & 657 & 20,617 \\
$\mathbf{1 9 7 7}$ & 21,815 & 863 & 20,952 \\
$\mathbf{1 9 7 8}$ & 20,486 & 1,046 & 19,440 \\
$\mathbf{1 9 7 9}$ & 27,450 & 1,378 & 26,073 \\
$\mathbf{1 9 8 0}$ & 24,551 & 2,337 & 22,214 \\
$\mathbf{1 9 8 1}$ & 17,133 & 3,643 & 13,470 \\
$\mathbf{1 9 8 2}$ & 15,382 & 3,442 & 11,940 \\
\hline & & & \\
\hline
\end{tabular}

\begin{tabular}{|c|c|c|c|}
\hline Year & Gas Produced & Gas Utilised & Gas Flared \\
\hline 1983 & 15,192 & 3,244 & 11,948 \\
\hline 1984 & 16,251 & 3,438 & 12,813 \\
\hline 1985 & 18,569 & 4,647 & 13,922 \\
\hline 1986 & 18,738 & 4,821 & 13,917 \\
\hline 1987 & 17,170 & 4,976 & 12,194 \\
\hline 1988 & 20,250 & 5,510 & 14,740 \\
\hline 1989 & 25,129 & 6,303 & 18,784 \\
\hline 1990 & 28,430 & 6,020 & 22,410 \\
\hline 1991 & 31,460 & 6,800 & 24,660 \\
\hline 1992 & 32,084 & 7,508 & 24,575 \\
\hline 1993 & 33,680 & 7,910 & 25,770 \\
\hline 1994 & 33,680 & 6,770 & 26,910 \\
\hline 1995 & 35,100 & 8,114 & 26,986 \\
\hline 1996 & 35,450 & 8,860 & 26,590 \\
\hline 1997 & 37,150 & 10,383 & 24,234 \\
\hline 1998 & 37,039 & 13,407 & 23,632 \\
\hline 1999 & 43,636 & 21,274 & 22,362 \\
\hline 2000 & 42,732 & 18,477 & 24,255 \\
\hline 2001 & 52,453 & 25,702 & 26,759 \\
\hline 2002 & $48,192.45$ & $23,356.87$ & $24,835.58$ \\
\hline 2003 & $51,766.03$ & 27,823 & $23,943.03$ \\
\hline 2004 & $58,963.61$ & $33,881.68$ & $25,090.91$ \\
\hline 2005 & $59,284.97$ & $36,282.27$ & 23002.71 \\
\hline 2006 & $82,063.86$ & $53,479.47$ & $28,584.39$ \\
\hline 2007 & $84,707.34$ & $57,400.21$ & $27,307.13$ \\
\hline 2008 & $80,603.61$ & $58,792.61$ & $21,811.00$ \\
\hline 2009 & $64,882.86$ & $46,895.27$ & $17,987.59$ \\
\hline $\begin{array}{c}\text { Grand } \\
\text { Total }\end{array}$ & $1,375,052.74$ & $480,898.10$ & $824,262.75$ \\
\hline
\end{tabular}

Source: [13].

\section{Top 8 Flaring Countries}

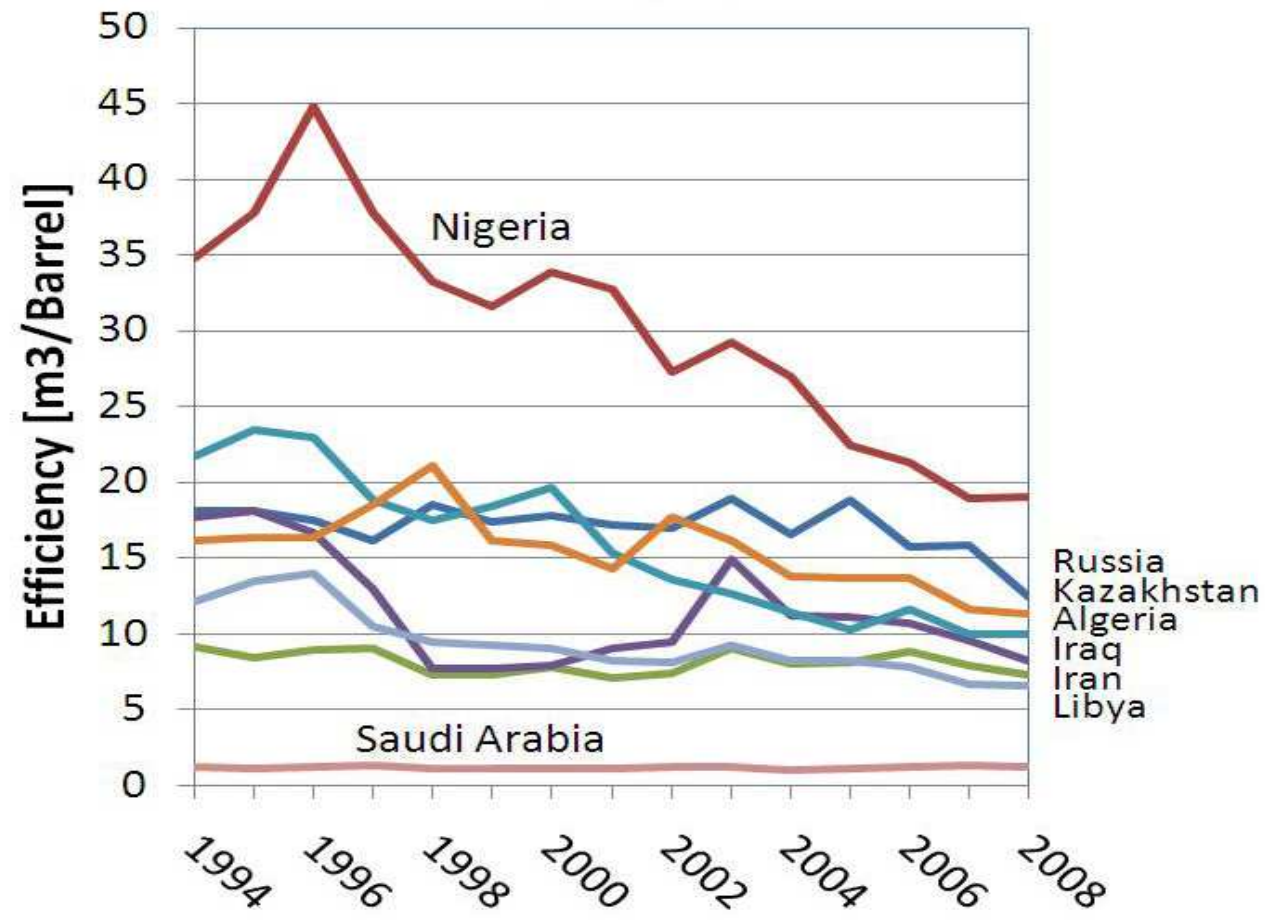

Fig. 2. Gas flaring efficiency of the top eight countries. Source: [11]. 
Table 2: Year 2008 top twenty gas flaring countries.

\begin{tabular}{lll}
\hline Rank & Country & Gas Flaring (BCM) \\
\hline $\mathbf{1}$ & Russia & 40.5 \\
$\mathbf{2}$ & Nigeria & 15.1 \\
$\mathbf{3}$ & Iran & 10.4 \\
$\mathbf{4}$ & Iraq & 7.0 \\
$\mathbf{5}$ & Algeria & 5.5 \\
$\mathbf{6}$ & Kazakhstan & 5.2 \\
$\mathbf{7}$ & Libya & 3.8 \\
$\mathbf{8}$ & Saudi Arabia & 3.5 \\
$\mathbf{9}$ & Angola & 3.1 \\
$\mathbf{1 0}$ & Qatar & 3.0 \\
$\mathbf{1 1}$ & Uzbekistan & 2.7 \\
$\mathbf{1 2}$ & Mexico & 2.6 \\
$\mathbf{1 3}$ & Venezuela & 2.6 \\
$\mathbf{1 4}$ & Indonesia & 3.2 \\
$\mathbf{1 5}$ & USA & 3.2 \\
$\mathbf{1 6}$ & China & 3.2 \\
$\mathbf{1 7}$ & Oman & 1.9 \\
$\mathbf{1 8}$ & Malaysia & 1.9 \\
$\mathbf{1 9}$ & Canada & 1.8 \\
$\mathbf{2 0}$ & Kuwait & 1.8 \\
\hline
\end{tabular}

Source: [11].

\section{Methodology}

The data used in this article were obtained from secondary sources, which are being used for the justification of the research problem (co-contamination of nitrate and aqueous organic pollutants resulting from crude oil extraction and refining processes) of the research we have embarked upon and, from which trying to explore remediation technique that can impact simultaneous remediation treatment to the coexist pollutants via heterogeneous photocatalysis using nanocrystalline $\mathrm{TiO}_{2}-$ based composite catalyst.

Table 3: Environmental Pollutants from Flared Natural Gas

\begin{tabular}{|c|c|c|c|c|c|c|c|c|c|c|}
\hline Year & 2011 & 2010 & 2009 & 2008 & 2007 & 2006 & 2005 & 2004 & 2003 & 2002 \\
\hline Hydrocarbon flared (million tonnes) & 3.4 & 3.6 & 2.6 & 2.8 & 3.4 & 4.8 & 7.0 & 8.1 & 8.1 & 6.8 \\
\hline Volatile organic compounds (VOCs) (thousand tonnes) & 111 & 133 & 126 & 130 & 148 & 185 & 199 & 213 & 226 & 324 \\
\hline Sulphur oxides $\left(\mathrm{SO}_{\mathbf{x}}\right)$ (thousand tonnes $\mathrm{SO}_{2}$ ) & 136 & 139 & 141 & 175 & 212 & 233 & 226 & 247 & 257 & 240 \\
\hline Nitrogen oxides $\left(\mathrm{NO}_{\mathrm{x}}\right)$ (thousand tonnes $\left.\mathrm{NO}_{2}\right)$ & 146 & 159 & 142 & 150 & 145 & 154 & 157 & 172 & 193 & 195 \\
\hline
\end{tabular}

Source: [14].

\subsection{Nitrate Sources and Chemistry in Oil and Gas Flared Region}

Nitrate is found in moderate concentrations in most of the natural waters. It occurs naturally due to the degradation of nitrogen-containing compounds from natural sources as soil, bedrock and organic materials [15]. Nitrate is also present as natural constituent of plants. Together with sulphates, nitrates are main components of acid rains [16]. However, the largest loading of nitrate originates from anthropogenic sources, which mostly result from excessive application of nitrate-based chemical fertilizers in agricultural activities [16, 17-19] and from many industrial processes [20-23], among which crude oil refining and extraction via gas flaring is the major and significantly contributing in oil and gas regions. Depending on the altitude, temperature, and radiation wavelength, initiation reactions take place in the atmosphere in form of photolytic reactions from where other stages of the reactions set in. The other three general steps in formation mechanism are propagation reaction, branching reaction, and terminating reaction with production of radicals of various forms which include: hydroxyl $\left(\mathrm{OH}^{*}\right)$, hydroperoxyl $\left(\mathrm{HO}_{2}{ }^{\circ}\right)$, methyl $\left(\mathrm{CH}_{3}{ }^{\circ}\right)$ and hydrogen $\left(\mathrm{H}^{\circ}\right)$. Any of these radicals may react with emission products from natural gas flares for the formation of secondary products that are of environmental concern [24], of which nitrate is inclusive. Considering the interaction between primary air pollutants released from natural gas flares [25], of which $\mathrm{NO}$ is one of them (the precursor of $\mathrm{NO}_{3}$ ), and the various atmospheric compositions which involve $\left(\mathrm{OH}^{*}\right)$, $\left(\mathrm{HO}_{2}{ }^{\circ}\right)$ and $\mathrm{O}_{3}$, a review of the reaction mechanism of the resulting secondary air pollutants $\left(\mathrm{NO}_{3}\right)$ is undertaken below:

$$
\begin{gathered}
\mathrm{NO}+\mathrm{HO}_{2}{ }^{\circ} \rightarrow \mathrm{NO}_{2}+\mathrm{OH}^{\cdot} \\
\mathrm{NO}_{2}+\mathrm{OH}^{\cdot} \rightarrow \mathrm{HNO}_{3}
\end{gathered}
$$

This formation of nitric acid is a function of the time of the day [26].

(During daytime)

$$
\begin{gathered}
\mathrm{NO}+\mathrm{HO}_{2}{ }^{\circ} \rightarrow \mathrm{NO}_{2}+\mathrm{OH}^{\bullet} \\
\mathrm{NO}_{2}+\mathrm{OH}^{\cdot} \rightarrow \mathrm{HNO}_{3}
\end{gathered}
$$


(At night)

$$
\mathrm{NO}_{2}+\mathrm{O}_{3} \rightarrow \mathrm{NO}_{3}+\mathrm{O}_{2}
$$

Or

$$
\begin{aligned}
& 2 \mathrm{NO}_{2}+\mathrm{O}_{3} \rightarrow \mathrm{N}_{2} \mathrm{O}_{5}+\mathrm{O}_{2} \\
& \mathrm{~N}_{2} \mathrm{O}_{5}+\mathrm{H}_{2} \mathrm{O} \rightarrow 2 \mathrm{HNO}_{3}
\end{aligned}
$$

This is a very key secondary particulate generally formed as a result of atmospheric reactions of $\mathrm{NO} / \mathrm{NO}_{2}$ involving gas to particle conversion [26]. In the lower troposphere, oxidized $\mathrm{NO}$ (Eqn. 2) and the emitted $\mathrm{NO}_{2}$ from natural gas flares, react with ozone to produce nitrate compound (Eqn. 3). The $\mathrm{HNO}_{3}$ produced from this reaction between $\mathrm{N}_{2} \mathrm{O}_{5}$ and $\mathrm{H}_{2} \mathrm{O}$ predominantly occurs in the cloud water and on the surface of particulate, involving the "charge transfer" or "ionic" intermediate $\mathrm{NO}_{2}{ }^{+}$and $\mathrm{NO}_{3}{ }^{-}$, with the product being nitrate aerosol and not gaseous $\mathrm{HNO}_{3}$ [27], which subsequently settle into soil and water bodies [28]. Nitrates are extremely soluble in water and can move easily through soil into the drinking water sources [23] and when their concentrations become excessive in water sources they cause several health and environmental problems.

\subsection{Nitrate Health and Environmental Concerns and Regulations}

Nitrate in water has low toxicity, but may be converted via microbacteria or in vivo reduction to nitrites $[29,16]$. Nitrites transform hemoglobin to methaemoglobin by oxidation of ferrous iron $\left(\mathrm{Fe}^{2+}\right)$ in hemoglobin to ferric form $\left(\mathrm{Fe}^{3+}\right)$ preventing or reducing the ability of blood to transport oxygen. Such a condition is described as methaemoglobinaemia which is dangerous especially in infants (so-called "blue-baby syndrome") [18-20, 22, 3032]. In addition, the reaction between nitrite and secondary or tertiary amines may result in the formation of carcinogenic, mutagenic and teratogenic $N$-nitroso compounds (N-nitrosamines) [29, 17, 20, 23, 32] which may cause cancer of the alimentary canal [21, 33-34]. In adults, high amounts of nitrate may cause abdominal pain, blood in stool and urine, weakness, mental depression [18], dyspepsia, headache [22], diarrhea, vomiting, diabetes, hypertension, respiratory tract infections and changes in the immune system [35]. In nature, high levels of nutrients, such as nitrates, lead to eutrophication of water sources, which in, severe cases, lead to the extermination of the other aquatic life due the decreased levels of oxygen and luminosity [36]. For these reasons, removal of nitrate from water is a necessity. To limit the risk to human health from nitrate in drinking water sources, the World Health Organization (WHO) set a maximum acceptable concentration to be $50 \mathrm{mg} \mathrm{NO}_{3}^{-} / \mathrm{L}$ [37].

\subsection{Organic Pollution Resulting from Oil and Gas Activities}

The global transport and use of both petroleum and its derivatives have made petroleum hydrocarbons (PHCs) major contaminants in both prevalence and quantity in the environment. Crude petroleum is mainly composed of linear and branched-chain alkanes, cycloalkanes and aromatics, but it also contains small amounts of oxygen-, nitrogen- and sulphur containing compounds, such as phenol, indole and thiophene, respectively [38]. Amongst the hydrocarbons, polyaromatic hydrocarbons (PAHs) are a class of compounds composed of two or more aromatic rings. They are a component of crude and refined petroleum products, which are released into the environment as a result of incomplete combustion of crude oil and thus, a lot to the extent of PAHs contamination especially in the aquatic and terrestrial environment occurred [39-42]. They have been reported in water samples, soil and sediments of the Niger Delta region of Nigeria which has had extensive petroleum production activities over the past few decades [43-45].

In addition, when crude oil hydrocarbons entred natural environment through crude oil spill, they are bound to under-go chemical transformation. The value of aromatic, straight chain hydrocarbons and the concentrations of chloride ion in the water samples of the Niger- Delta region of Nigeria, shows that the formation of chlorinated aromatic and polychlorinated-n-alkanes (PCAs) are possible [46]. They are normally manufactured in the presence of ultra violet (UV) light [47]. The surface water of the region where crude oil spill occurs are wide open to direct ultra violet (UV) light from the sun, their formation is by simple substitution of hydrogen atom(s) by chlorine radical, an example of chain reaction involving free radicals [48], also for the fact that the temperatures of water are above ambient values even in rainy season [46] shows that their formation is possible (see eqn. 4 and 5). Those of great interest are the benzene, phenol and $\mathrm{C}_{10}-\mathrm{C}_{13}$ PCAs, which have the greatest potential for environmental release [49] and the highest toxicity of their products [50-51].

$$
\begin{gathered}
\mathrm{H}_{\mathrm{y}} \mathrm{C}_{\mathrm{x}}+\mathrm{Cl}^{\cdot}+h v \rightarrow \mathrm{H}_{\mathrm{y}-1} \mathrm{C}_{\mathrm{x}}+\mathrm{HCl} \\
\mathrm{H}_{\mathrm{y}-1} \mathrm{C}_{\mathrm{x}}+\mathrm{Cl}^{\bullet} \rightarrow \mathrm{H}_{\mathrm{y}-1} \mathrm{C}_{\mathrm{x}} \mathrm{Cl}
\end{gathered}
$$

Furthermore, In addition above, formation of aerosols which are called secondary organic aerosol (SOAP) which depend strongly on the conversion of volatile organic compounds (VOCs) is possible [52], which also has negative environmental impact released from the gas flares an operational unit of oil and gas activities. Though aerosol formation from primary air pollutants resulting from natural gas flares emissions usually takes place outdoor, the impacts on the environment may include indoor [53].

\subsection{Health and Environmental Concerns and Regulations of Petroleum Organic Pollutants}

Commercial exploration and exploitation of huge crude oil deposits and gas reserves in the Niger-Delta region of Nigeria has resulted in the alteration of the region's environment in certain negative manner. Petroleum 
hydrocarbon has the potential to eliciting various toxic effects, which can cause acute lethal toxicity, sub lethal chronic toxicity or both depending on the exposure, dosage and type of organism exposed [54]. Accumulation of differed categories of pollutants from drilling, production, refining of crude oil and production of petrochemicals has been a legacy of environmental pollution (of land and water) and destruction. Amongst the petroleum hydrocarbons, those of great interest are the chlorinated aliphatic of $\mathrm{C}_{10}-$ $\mathrm{C}_{13}$ PCAs, benzene, polyaromatic hydrocarbons and chlorinated aromatics, which have the greatest potential for environmental release [49] and the highest toxicity of chlorinated hydrocarbons products $[50-51,55]$. Taken together, the carcinogenic effect of chlorinated aliphatic and polyaromatic hydrocarbons (PAHs) and the fact that study has shown that the $\mathrm{C}_{10}-\mathrm{C}_{13}$ PCAs inhibit intercellular communication in rat liver epithelial cells, a phenomenon that suggests these chemical may be acting as tumor promoters [54], could accelerate environmental and public health hazards such as malignant lymphomas [56-57] and soft tissues sarcomas [58], which already reported in the Niger Delta region of Nigeria [54]. In addition, because of complex composition of crude oil, it has multiple potential type of toxic effect which may include long term petroleum pollution on individual organism such as impaired reproduction [59], reduced growth [60], tumours and lesions [61], and morphological abnormalities [62]. Therefore, to institute control, PAHs and chlorinated hydrocarbons, such as chlorinated phenols are classified as environmentally hazardous organic compounds due to their known or suspected carcinogenicity and are included in the European community (EC) and United States Environmental Protection Agency (USEPA) priority pollutant list [63-65] and thus, soil or water bodies containing these require remediation. In the same vein, the maximum contamination levels for chlorinated aliphatic and benzene in the environment are set to be $0.005 \mathrm{mg} / \mathrm{L}$.

\section{Conclusion}

From this survey, the continued and unabated flaring of gas in Niger-Delta, Nigeria is deemed to be the prime source of release and co-contamination of nitrate and hydrocarbon pollutants among the other anthropogenic sources and thus, deserve given attention. This continued release of nitrate and hydrocarbon pollutants via flaring of gas has resulted in massive degradation of the region with the attendant destruction of the natural ecosystem and human health. Therefore, a solution to this problem (gas flaring) and the attendants damaged so far done through continued release of nitrate (via nitrate precursor, i.e. $\mathrm{NO}_{\mathrm{x}}$ ) and organic pollutants to the general ecosystem of the region require integrated laws and policies to avert the practice. This together with holistic remediation technique for the simultaneous destruction of the coexist pollutants at low cost operation and also be possibly installed even at remote locations of the region.

\section{Acknowledgement}

Full funding of our $\mathrm{PhD}$ studentship at Aberdeen University by Petroleum Technology Development Fund (PTDF), Nigeria is warmly acknowledged. In addition, the authors acknowledged and are grateful to the Nigerian National Petroleum Corporation, as well as Energy Commission of Nigeria for the provision of historic and upto-date data on the gas flaring in Nigeria, which served as the basis of the justification of the historic cocontamination problem in the oil and gas hub of the country.

\section{References}

[1] Markham, A. 1994. A brief history of pollution, Earthscan Publication, London.

[2] Macklin, M.1992. In: Newson, M. (Ed), Managing the human impact on the natural environment: Patterns and process. Belhaven Press, London.

[3] Wedepohl, K.H. 1991. Metals and their compounds in the environment. VCH, Weinhien, pp. 3-7.

[4] U.S. Energy Information Administration (USEIA) 1997. "Nigeria Country Analysis Brief".

[5] Eteng, I.A. 1997. The Nigerian State, oil exploration and community interest: "Issues and perspectives" University of Portharcourt, Nigeria. p. 4.

[6] Leahey, D. M., Preston, K., Strospher, M. 2001. Theoretical and observational assessment of flare efficiencies. J. Air Waste Manag. Assoc., 51(12), 1610-1616.

[7] United States Environmental Protection Agency (USEPA) 2013. Retrieved from www.epa.gov on 11/05/2013.

[8] Ishishone, M. 2004. Gas flaring in the Niger-Delta: The potential benefits of its reduction on the local economy and environment. Retrieved from http://socrates.berkeley.edu/ es196/projects/2004final/ishiso ne.pdf on 15/04/2013.

[9] Mark, M. 2012. Nigeria's penalty for gas flaring will not curb emission. Retrieved from www.guardian.co.uk/environment/oil on 20/04/2013.

[10] Oni, S. I. and Oyewa, M. A. 2011. Gas flaring, transportation and sustainable energy development in the Niger-Delta, Nigeria. J. Hum. Ecol., 33(1), 22-28.

[11] Elvidge, D., Ziskin, D., Baugh, B., Tuttle, B., Ghosh, T., Pack, D., Erwin, E. and Zhizhin, M. A. 2009. Fifteen year record of global natural gas flaring derived from satellite data. Energies, 2(3), 595-622.

[12] Adebayo, S. 2010. Itsekiri women shut down $\$ 800 \mathrm{~m}$ gas project. The punch, July, 19, 2010. p. 8.

[13] Nigerian National Petroleum Corporation (NNPC). 2009. Year 2009 annual statistical bulletin.

[14] Shell Petroleum Development Company (SPDC), Nigeria2011. Year 2011 sustainability report. p. 32.

[15] Hagerty, P. A. and Taylor, J. R. 2012. Retrieved from http://www.taylorgeoservices.com/papers.on 26/12/2012. 
[16] Mikuska, P. and Vecera, Z. 2003. Simultaneous determination of nitrite and nitrate by chemiluminescent flow-injection. Analytica Acta, 495, 225-232.

[17] Rocca, C. D., Belgiorno, V. and Meric, S. 2007. Overview of in-situ applicable nitrate removal processes. Desalination, 204, 46-62.

[18] Betheja, K., Sinha, A. K. and Seth, G. 2009. Studies on water treatment for removal of nitrate. Asian J. Exp. Sci., 23(1), 61-66.

[19] Ozturk, N. and Bektas, T. E. 2004. Nitrate removal from aqueous solution by adsorptiononto various materials. J. Hazard. Mater., 112, 155-162.

[20] Mizata, K., Matsumoto, T., Hatate, Y., Nishihara, K. and Nakanishi, T. 2004. Removal of nitrate-nitrogen from drinking water using bamboo powder charcoal. Biores. Technol., 95, 255-257.

[21] Ozturk, N. and Kose, T. E. 2008. A kinetic study of nitrite adsorption onto sepiolite and activated carbon. Desalination, 223,174-179.

[22] Okafor, N. P. and Ogbonnna, U. I. 2003. Nitrate and nitrite contamination of water sources and fruit juices marketed in South-Easter Nigeria. J. Food Comp. Anal., 16,213-218.

[23] Mishra, P. C. and Patel, R. K. 2009. Use of agricultural waste for the removal of nitrate-nitrogen from aqueous medium. J. Environ. Manag., 90, 519-522.

[24] Sonibore, J. A. 2011. A Critical Review of Natural Gas Flares-Induced Secondary Air Pollutants.Global Nest Journal, 13(1), 74-89.

[25] Sonibore, J. A. and Akeredolu, F. A. 2004. A theoretical prediction of non-methane gaseous emissions from natural gas combustion. Energy Policy, 32(14), 1653-1665.

[26] Bettenheim, J. M., Brice, K. A. and Anlauf, K. G. 1984. Discussion of a lagrangian trajectory model describing longrange transport of oxides of nitrogen, the incorporation of PAN in the chemical mechanism, and supporting measurements of PAN and nitrate species at rural sites in Ontario, Canada, Atmospheric Environment, 1967 18(12), 2609-2619.

[27] Michalski, G., Bohlke, J. K. and Thiemens, M. 2004. Long term atmospheric deposition as the source of nitrate and other salts in the Atcama Desert, Chile: New evidence from mass-independent oxygen isotopic composition. Geochimicaet Cosmochimica Acta, 68(2), 4023-4038.

[28] Raputa, V. F., Smolyakov, B. S. and Koutzenogu, K. P. 2008. Estimation of nitrate and sulphate content in snow in the vicinity of an oil-gas flare.J. Aerosol Sci.,30,S655-S656.

[29] Mikuska, P. and Vecera, Z. 2002. Chemiluminescent flowinjection analysis of nitrate in water using on-line ultraviolet photolysis.Analytica Chemica Acta,474, 99-105.

[30] Grommen, R. Hauteghem, I. V., Wambeke, M. V. and Verstraete, A. 2002. Animproved nitrifying enrichment to remove ammonium and nitrite from freshwater aquaria systems Aquaculture, 211, 115-124.

[31] Shrimali, M. and Singh, K. P. 2001. New methods of nitrate removal from water. Environ. Pollut., 112(3), 351-359.

[32] Melchert, W. R., Carlos, M. C. and Infante, R. P. Rocha.
2007. Development and critical comparison of greener flow procedures for nitrite determination in natural waters. Micro-chemical Journal, 85, 209-213.

[33] Afkhami, A. Mandrakian, S. and Karimi, Z. 2007. The effect of acid treatment of carbon cloth on the adsorption of nitrite and nitrate ions. J. Hazard. Mater., 144, 427-431.

[34] Rezaee, A.,Godini, S., Dehestani, S. and Khavani, A. 2008. Application of impregnated almond shell activated carbon by zinc and zinc sulphate for nitrate removal from water. Iran J. Health. Sci. Eng.,5(2), 125-130.

[35] Lohumi, N., Gosain, S., Jain, A., Gupta, V. K. and Verma, K. K. 2004. Determination of nitrate in environmental water samples by conversion into nitrophenols and solid phase extraction-spectrophotometry, liquid chromatography or gas chromatography-mass spectrometry. Analytica Chimica Acta, 505(2), 231-237.

[36] Anderson, J. A. and Fernandez-Gacia, M. 2009. Catalytic and photocatalytic removal of pollutants from aqueous sources. Catalysis, 21, 51-81.

[37] World Health Organisation (WHO) 2006.Guideline for drinking water quality, first Addendum, $3^{\text {rd }}$ edn.

[38] Meenu, T. M., Manuela, R., Fonseca, D., Carla, C. C. R. and Carvalho, D. 2011. Bioaugmentation and biostimulation strategies to improve the effectiveness of bioremediation processes. Bioremediation, 22, 231-241.

[39] Baek, S. O., Field, R. A., Gold-stone, R. A., Kirk, P. W., Lester, J. N. and Perry, R. 1991. A review of atmospheric polycyclic aromatic hydrocarbons: sources, fate and behaviour. Water, Air, Soil Pollut., 60, 279.

[40] Lorber, M., Cleverly, D., Schuam, J., Phillips, L., Schweer, G. and Leighton, T. 1994. Development and validation of an air-to-beef food chain model for dioxin-like compounds. Environ. Sci. Technol., 156, 39-65.

[41] Nwachukwu, S. C. U. 2000. Enhanced rehabilitation of tropical aquatic environment polluted with crude oil petroleum using Candida utitis. J. Environ. Biol.,21, 241250.

[42] Nwachukwu, S. C. U., James, P. and Gurney, T. R. 2001. Impacts of crude oil on the germination and growth cress seeds (Lepidium sp.) after bioremediation of agricultural soil polluted with crude petroleum using adapted Pseudomonas putida. J. Environ. Biol., 22, 29.

[43] Anyakora, C., Palmer, P., Coker, H., Ukpo, G. and Ogah, C. 2005. GC/MS analysis of polynuclear aromatic hydrocarbons in sediment samples from Niger-Delta region. Chemosphere, 60, 990 - 997.

[44] Anyakora, C. and Coker, H. 2006. Determination of polynuclear aromatic hydrocarbons (PAHs) in selected water bodies in the Niger-Delta. Afric. J. Biotechnol., 5(21), 20242031.

[45] Anyakora, C., Ogbeche, A., Palmer, P., Coker, H., Ukpo, G. and Ogah, C. 2005. Determination of polynuclear aromatic hydrocarbons in marine samples of Siokolo fishing settlement. J. Chromatography, A, 1073, 323-330.

[46] Nduka, J. K. and Orisakwe, O. E. 2011. Assessment of pollution profile of selected surface water in the Niger-Delta region of Nigeria. Lambert Academic Publishers, Germany. 
[47] Tomy, G. T., Fisk, A. T., Westmore, J. B. and Muir, D. C. G. 1998. Environmental chemistry and toxicology of polychlorinated n-Alkanes. Rev. Environ. Contam.Toxicol., $158,53-128$.

[48] Morrison, R. T. and Boyd, R. N. 1983. Organic Chemistry, $4^{\text {th }}$ ed., Allyn and Bacon Newton, MA.

[49] Environmental Canada. Priority Chemicals Branch, 1993a.

[50] Serrone, D. M., Birtly, R. D. W., Weigand, W. and Millischer, R. 1987. Toxicology of chlorinated paraffin. Food Chem. Toxicol., 25, 553-562.

[51] Mukherjee, A. B. 1990. The use of chlorinated paraffin and their possible effects in the environment.National board of waters and the environment, Helsink, Finland. Series A66.National Board of waters and the environment, Helsinki, Finland.

[52] Dechapanya, W., Eusebi, A., Kimura, Y. and Allen, D. T. 2003. Secondary organic aerosol formation from aromatic precursors: 1. Mechanisms for individual hydrocarbons. Environ. Sci. Technol., 37(16), 3662-3670.

[53] Gauvin, J., Reungoat, P., Cassadai, S., Dechenaux, J., Momas, I., Just, J. and Zimirou, D. 2002. Contribution of indoor and outdoor environments to $\mathrm{PM}_{2.5}$ personal exposure of children VESTA Study. Sci. Total Environ., 29, 175-181.

[54] Nduka, J. K., Obumselu, F. O. and Umedum, N. L. 2012. Crude oil and fractional spillage resulting from exploration and exploitation in Niger-Delta region of Nigeria: A review about the environmental and public health impact. Retrieved fromwww.intechopen.book/crude-oil-explorationinthe world/environmental impact/com. on 15/11/2012.

[55] Wills, B., Crookes, M. J., Diment, J., Dobson, S. D. 1994.Toxic Substances Division, Dept. of Environ., Garston, UK.
[56] Omati, C. E. and Halim, N. K. 2005. Adult lymphomas in Edo State, Niger Delta region of Nigeria- Unicopathological profile of 205 cases. Clin. Lab. Haematol., 27(5), 305-306.

[57] Omati, C. E. 2006. Socio-demographic factors of adult malignant lymphomans in Benin City, Nigeria. Niger. Postgrad. Med. J., 13(3), 256-260.

[58] Seleye-fubara, D., Nwosu, S. D. and Yellowe, B. E. 2005. Soft Tissue sarcomas in the Niger Delta Region of Nigeria (a referral hospital study). Niger. J. Med., 14(2), 188-198.

[59] Feuston, M. H., Hamilton, C. E., Schreiner, C. A. and Mackerer, C. R. 1997. Developmental toxicity of dermally applied crude oils in rats. J. Toxicol. Environ. Health, 52, 79-93.

[60] Eisler, R. 1987.A Synoptic Review: Fish and Wild-life Service, US Dept. of Interior, pp. 1-11.

[61] Malins, D.C. and Ostrander, G. K. 1994. Aquatic Toxicology, Lewis publishers, Chelsea, MI.

[62] Kennish, M. J. 1997. Marine Pollution, Boca Ratan, FL: CRC Press, pp. 83-95.

[63] Nieva-cano, M. J., Rubio-Barroso, S. and Santos- Delgano, M. J. 2001. Determination of PAH in food samples by HPLC with flourimetric detection following sonication extraction without sample clean-up. The Analyst,1126, 1326-1331.

[64] United State Environmental Protection Agency (USEPA) $2012 . \quad$ Retrieved from www.epa.gov./waterscience/standardson 30/12/12.

[65] European Commission. 2001. Establishing the list of priority substances in the field of water policy and amending Directive. Decision No 2455/2001/EC of the European parliament and the council of the European Union. 